\title{
Spatial distribution and temporal evolution of leprosy in an area of an old colony in the state of Pará
}

\author{
Distribuição espacial e evolução temporal da hanseníase em uma área de antiga colônia \\ no estado do Pará
}

Distribución espacial y evolución temporal de la hanseniasis en un área de antigua colonia en el estado de Pará

Geraldo Mariano Moraes de Macedo ${ }^{1 *}$, Marcos Fabiano de Almeida Queiroz ${ }^{1}$, Alison Ramos da Silva ${ }^{1}$, Bruno Vinícius da Silva Pinheiro ${ }^{1}$, Mariane Cordeiro Alves Franco ${ }^{1}$, Marília Brasil Xavier ${ }^{1}$.

\begin{abstract}
Objective: To identify the pattern of spatial distribution and temporal evolution of leprosy, taking into account the clinical, demographic and territorial aspects of Vila Santo Antônio do Prata, a municipality considered to be hyperendemic, in the state of Pará from 2003 to 2013. Methods: This is a ecological, observational and retrospective study. The study was the former colony of leprosy, now known as the Vila de Santo Antônio do Prata. Results: High rates of detection of new cases of leprosy were observed with a hyperendemic detection coefficient from 2003 to 2009. The spatial distribution of total cases of leprosy presents a pattern of distribution with several outbreaks, in which the incidence of multibacillary cases. The trend estimates for 2020 has shown that Brazil will maintain the index in slow and gradual reduction, while the state of Para will continue with high rates of hyperendemicity and the municipality of Igarapé-Açu will surpass the North region. Conclusion: It is suggested that there is an active transmission dynamic in Vila Santo Antônio do Prata area evaluated with the need for constant monitoring of new cases of leprosy.
\end{abstract}

Keywords: Leprosy, Spatial analysis, Epidemiological monitoring.

\section{RESUMO}

Objetivo: Identificar o padrão de distribuição espacial e evolução temporal da hanseníase, levando em consideração aspectos clínicos, demográficos e territoriais da Vila Santo Antônio do Prata, município considerado hiperendêmico, no estado do Pará de 2003 a 2013. Métodos: Trata-se de um estudo ecológico, observacional e retrospectivo. O estudo teve como unidade de análise, a ex-colônia de hansenianos, conhecida atualmente como Vila de Santo Antônio do Prata. Resultados: Verificou-se altas taxas de detecção de casos novos de hanseníase apresentando coeficiente de detecção hiperendêmico no período de 2003 a 2009. O mapa da distribuição espacial dos casos totais de hanseníase apresenta um padrão de distribuição com diversos focos, nos quais se concentram as maiores incidências de casos multibacilares. A estimativa de tendência para 2020 demonstrou que o Brasil manterá o índice em redução lenta e gradativa, enquanto o estado do Pará seguirá com índices elevados de hiperendemicidade e o município de Igarapé-Açú superará a região Norte. Conclusão: Sugere-se que há a existência de uma dinâmica ativa de transmissão na área da Vila Santo Antônio do Prata avaliada com necessidade de monitoramento constante de novos casos de hanseníase.

Palavras-chave: Hanseníase, Análise espacial, Monitoramento epidemiológico.

${ }^{1}$ Universidade Federal do Pará, Núcleo de Medicina Tropical, Belém, Pará, Brasil.

*E-mail: geraldo mmm@yahoo.com.br 


\section{RESUMEN}

Objetivo: Identificar el patrón de distribución espacial y evolución temporal de la lepra, teniendo en cuenta aspectos clínicos, demográficos y territoriales de Vila Santo Antônio do Prata, municipio considerado hiperendémico, en el estado de Pará de 2003 a 2013. Métodos: Se trata de un estudio ecológico, observacional y retrospectivo teniendo. El studio tuvo como unidad de análisis, la ex colonia de hansenianos, conocida actualmente como Vila de Santo Antônio do Prata. Resultados: Se verificaron altas tasas de detección de casos nuevos de hanseniasis presentando coeficiente de detección hiperendémico en el período de 2003 a 2009. El mapa de la distribución espacial de los casos totales de hanseniasis presenta un patrón de distribución con diversos focos, en los cuales se concentram las mayor incidencia de casos multibacilares. La estimación de tendencia para 2020 demostró que Brasil mantendrá el índice en una reducción lenta y gradua, mientras que el estado do Pará seguirá con índices elevados de hiperendemicidad y el municipio de Igarapé-Açú superará la región Norte. Conclusión: Se sugiere que existe la dinámica activa de transmisión en el área de Vila Santo Antônio do Prata evaluada con necesidad de monitoreo constante de nuevos casos de hanseniasis.

Palavras clave: Hanseniasis, Análisis especial, Monitoreo epidemiológico.

\section{INTRODUCION}

Leprosy is a chronic infectious disease of compulsory notification. It has a great ability to generate dermatological lesions and loss of thermal, painful and tactile sensitivities and, when untreated, is capable to developing permanent physical disabilities (MINISTÉRIO DA SAÚDE, 2016). It is caused by Mycobacterium leprae, an obligate intracellular bacillus with affinity for Schwann cells of the peripheral nervous system (RIDLEY DS, JOPLING WH, 1966).

Transmission occurs through the direct, continuous and long-term contact of susceptible persons with untreated bacilliferous patients, and the route of entry and elimination of the bacillus is the upper respiratory tract (RIDLEY DS; JOPLING WH, 1966). Some studies of the epidemiology of leprosy discuss the role of the history of the occupation of the territories as a basis for the maintenance of outbreaks of the disease associated with unfavorable conditions of life, considering economic, hygienic-sanitary and biological factors (IÑIGUEZ $\mathrm{RL}$, et al, 1993).

The distribution of cases in Brazil is heterogeneous and although the prevalence rate ranges from 17 cases to 100,000 inhabitants, in the states of Pará, Maranhão, Bahia, Minas Gerais and Goiás, the values are about 10 times higher than the average national. The precariousness of primary health care combined with the lack of knowledge of the disease contributes to the fact that leprosy is the major cause of physical disability and social stigma due to its diagnosis (SOUZA W, 2010).

According to some authors, spatial analysis techniques can become effective tools in managing the leprosy elimination program (QUEIROZ JW, et al., 2010; AMARAL EP, LANA FCF, 2008; LANA FCF, 2004; BARRETO JG, 2013).

In the case of leprosy, the use of the Geographic Information System (GIS) can help to monitor the extent of treatment coverage by multidrug therapy, provide a graphical analysis of the epidemiological indicators, show the spatial distribution of the disease, identify areas with high endemicity and indicate those with the need to allocate extra resources. GIS can therefore be seen as a valuable management tool for the leprosy elimination program, such as strengthening national, regional and subregional capacities for surveillance and monitoring (WHO, 2015).

Despite the varous advances in the use of GIS, timid studies are being developed in the State of Pará, which holds one of the highest detection loads of leprosy in Brazil (MINISTÉRIO DA SAÚDE, 2016). The scarce data on the spatial distribution of the cases in Pará are aggregated by municipalities or regions and do 
not allow the localization of critical areas within the cities for the direction of control actions (PENNA ML, et al., 2009; QUEIROZ JW, et al., 2010; ALENCAR CH, et al., 2012). This study aimed to identify the temporal evolution of leprosy in the area of the former colony of leprosy in the community of Vila Santo Antônio do Prata (Igarapé-Açú), a hyperendemic municipality in the State of Pará, from 2003 to 2013.

\section{METHODS}

This is an ecological, observational and retrospective study, having as an analysis unit an area of an old colony of leprosy, now known as Vila de Santo Antônio do Prata, located in the municipality of Igarapé-Açú, in the State of Pará, northern Brazil. The temporal and spatial pattern of leprosy was analyzed from the detection of new cases available in the Information System of Notifiable Diseases and in the municipal health agency of the municipality of Igarapé-Açú. Data collection took place after approval of the research project in the Ethics Committee in Research with Human Beings (CEP) of the Federal University of Pará (UFPA) / Nucleus of Tropical Medicine (opinion no. 1,213,470), obeying Resolution 466 / 2012 of the National Health Council. We included in the study all new cases diagnosed between the years 2003 to 2013, according to the place of residence at the time of diagnosis.

For the spatial analysis we excluded the cases in which it was not possible to georeferentiate, due to inconsistencies in the address data and due to the change of domicile of the case. At the end, we totaled 226 patients for analysis of classic statistics and 183 patients for spatial statistics. The classic statistic was performed in the program Bioestat 5.0 to generate statistical results, considering the $95 \%$ confidence interval $(\mathrm{Cl})$ and the level of $\alpha 5 \%$ ( $p$-value $\leq 0.05$ ). For the trend analysis, the data were evaluated by the curve fitting test to verify the time model that best suited the presented data.

The dependent variables $(\mathrm{Y})$ for each analysis were the logarithms of the annual rates of detection of general leprosy, while the independent variables, the calendar years of the analyzed period. Thus, first, second, and third order linear polynomial regression models represented by the following mathematical equations were generated: i) $\log Y=\beta 0+\beta 1 X$; ii) $\log Y=\beta 0+\beta 1 X+\beta 2 X 2$ and iii) $\log Y=\beta 0+\beta 1 X+\beta 2 X^{2}$ $+\beta 3 X 3$. The time distribution estimates were evaluated until the year 2020 with trend curves created for Brazil, the Northern region, Pará state and Igarapé-Açu municipality.

The spatial delimitation of the micro-areas was performed using a GPS device (72 CSx "trackmaker", Garmin). A team member with the help of the community health agents (ACS) of each micro-area traveled the addresses marking the geographical coordinates, in the end, these data were interconnected for the generation of polygons, which represented the boundaries between the respective seven micro -areas.

At the time of geographical markings there were residences composed of more than 1 case of leprosy, so in order to avoid generating the analysis, the same coordinates were repeated, so the analysis of the density of the cases resulted in a real detection coefficient of the micro-areas corresponding to the endemicity parameter used by the World Health Organization (WHO):

$$
C D=\left(\frac{\text { number of cases }}{\text { population }}\right) * 10.000
$$

Finally, for the events of representation of the micro-areas, the geographic information was stored and analyzed by the programs ArcGis 10.2 and Terra View 4.2.2. Spatial density patterns were obtained through the Kernel softening technique, taking into account the areas of greatest concentration of leprosy cases. The Moran geostatistics technique was used to identify if there was a spatial correlation between areas composed of new cases of leprosy and areas composed of multibacillary (MB) cases, which in the end generated an index ranging from -1 to +1 , obtaining three characteristics: (i) when there is no spatial correlation, the index approaches 0 , (ii) when there is a direct correlation and (iii) if there is a negative correlation, there is an inverse correlation.

\section{RESULTS}

The trend analysis demonstrated in figure 1 showed a significant reduction in the annual detection coefficient at national level. The northern region and the state of Pará also presented a reduction in the index, 
however they still presented hyperendemic levels. In the municipality of Igarapé-Açú, a reduction in the detection coefficient was observed, from hyperendemic at the beginning of the observation to a condition of high endemia. Thus, it was possible to identify three (3) episodes, which, the coefficient of detection of new cases in the municipality (Vila Santo Antônio do Prata) exceeded the detection rates of the state of Pará and the North region (Figure 1).

Figure 1 - Trend Analysis and Coefficient of Detection of New Cases of Leprosy.

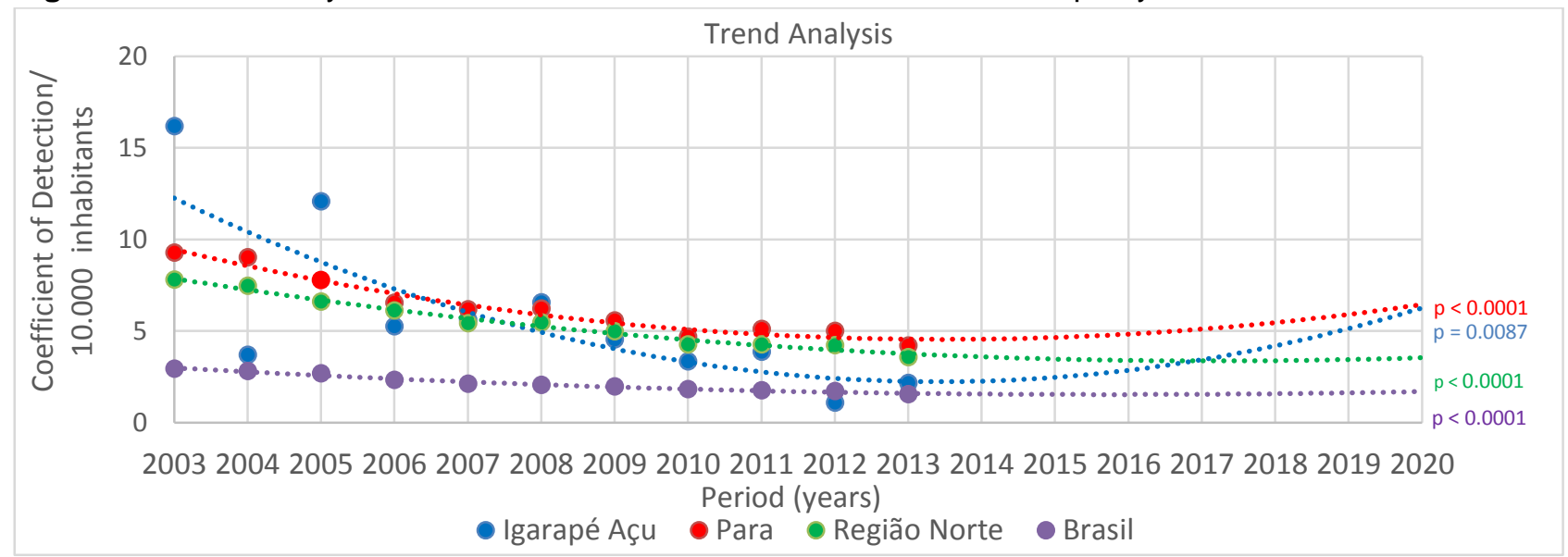

Source: Research Laboratory in Tropical Dermatology and Endemic Diseases (LABDERMTROP - UFPA).

The map of the spatial distribution presented a pattern of distribution of the mosaic-like points, presenting several focuses around which the highest incidence of health problems was concentrated. Among these outbreaks, a greater number of multibacillary cases (MB) were observed throughout the community (Figure 2).

Figure 2 - Spatial distribution of leprosy cases according to the Operating Classification in Microareas in Vila Santo Antônio do Prata.

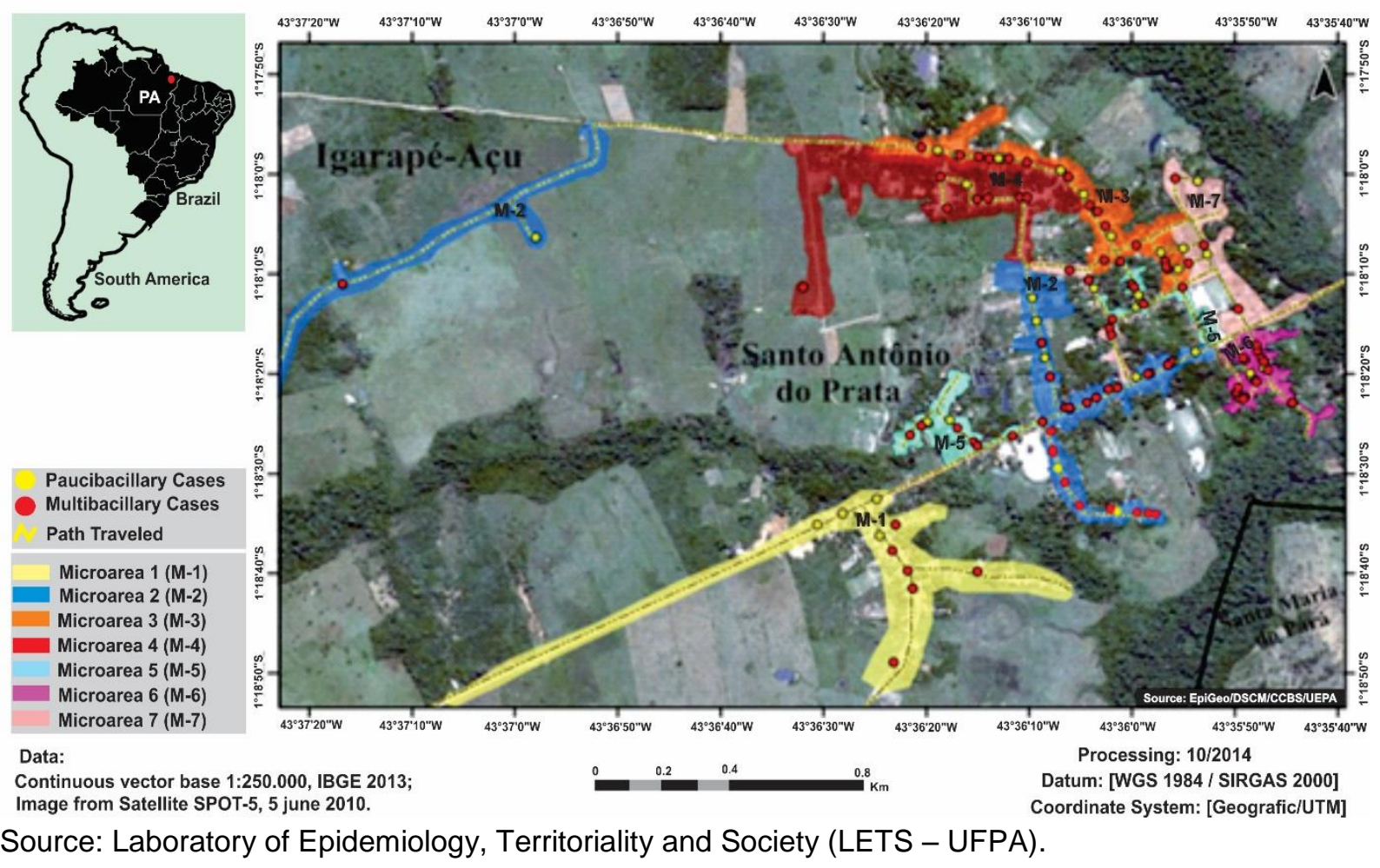


Through the Kernel estimation, a map of the spatial distribution of leprosy was developed, which revealed "hot areas" corresponding to a greater number of cases detected in a certain area. With this, it was possible to identify 2 high concentration episodes in microarea 6 and of intermediate concentration in microarea 5 (Figure 3).

Figure 3 - Spatial Distribution of Cases of Leprosy in Microareas using the Kernel Estimate in Vila Santo Antônio do Prata.
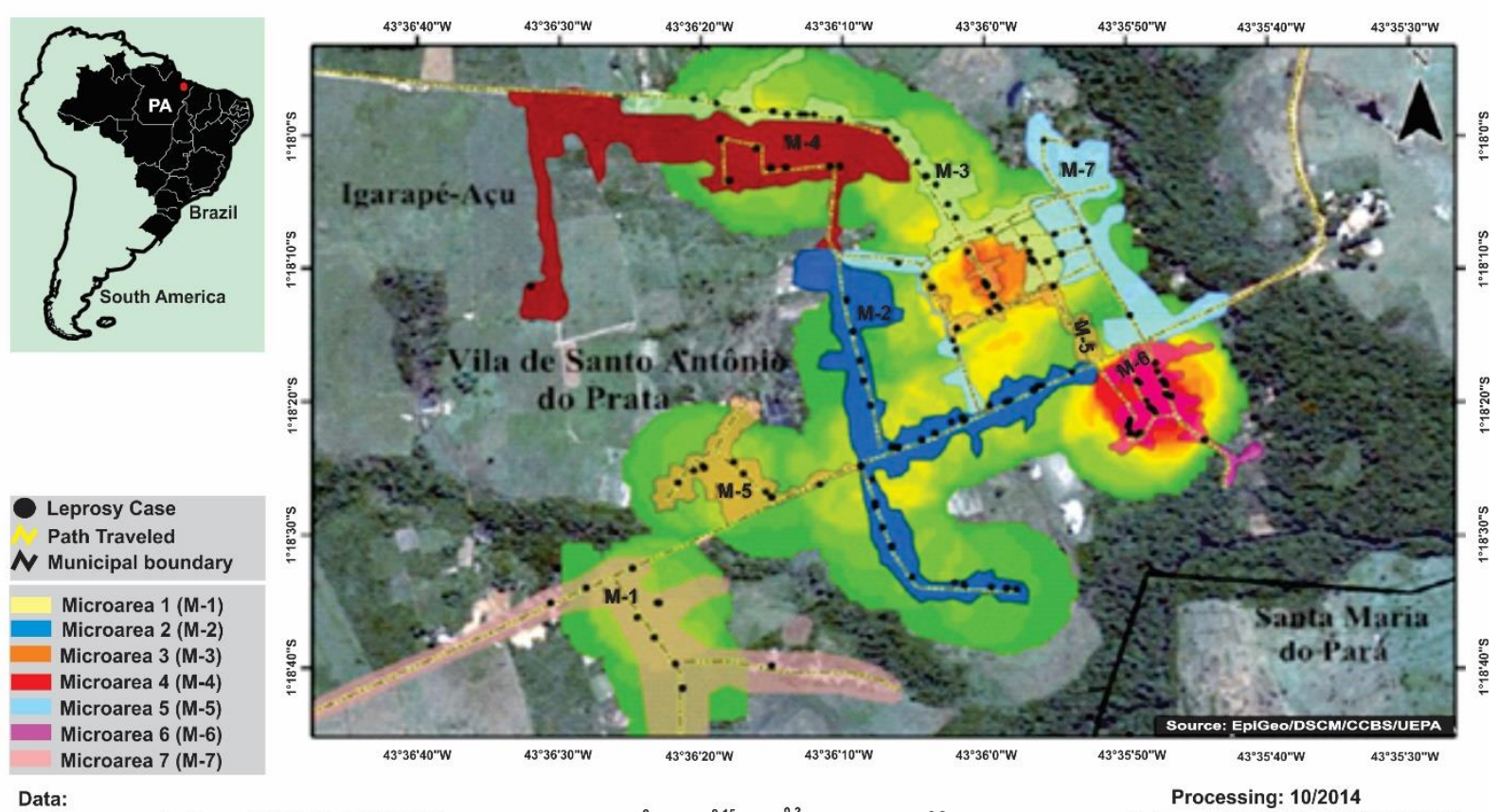

Data:

Continuous vector base 1:250.000, IBGE 2013; Image from Satellite SPOT-5, 5 june 2010.

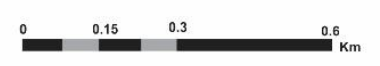

Datum: [WGS 1984 / SIRGAS 2000] Coordinate System: [Geografic/UTM]

Source: Laboratory of Epidemiology, Territoriality and Society (LETS - UFPA).

\section{DISCUSSION}

The general coefficient of detection of new cases of leprosy (cases / 10,000 inhabitants), an important index of surveillance and control of the disease showed important variations during the period of research with reduction at the national, regional, state and even municipal level; the same observed by researchers who observed a decreasing trend in the number of cases of leprosy and in the time series of detection coefficients between 1990 and 2008 (PENNA ML, et al., 2009). This downward trend in Brazil from 2003 can be explained by the implementation of the National Plan for Mobilization and Intensification of Actions for the Elimination of Leprosy by the Ministry of Health in November 2002. It is also important to note that Brazil assumed the presidency of the Alliance Global Alliance for the Elimination of Leprosy in 2002, which contributed to increasing the responsibility and commitment of leprosy. the country in actions to control and combat leprosy (SILVA FL, SILVA AL, 2011).

The northern region and the state of Pará presented a gradual reduction in the detection coefficients, but they remained hyperendemic ( $>4$ cases / 10,000 inhabitants) throughout the observation period. Studies have observed a graphical symmetry in the distribution of cases in the dynamism of the temporal evolution of the occurrences of new cases in the North region, whose influence is intrinsically linked to the reports of new cases registered in the state of Pará (SILVA FL, SILVA AL, 2011).

The municipality of Igarapé-Açu had high rates of detection of new cases of leprosy with oscillations presenting a hyperendemic detection coefficient between 2003 and 2009, identifying three moments in which the coefficient of detection of new cases exceeded the indexes of the disease compared to the state of Pará and the North region. Similar behavior was observed in the city of Fernandópolis (SP), considered 
hyperendemic and with a history of high detection coefficients of new cases. It can be observed that, although the patients are being treated and cured, the chain of transmission continues active (MERCARONI DA, 2003). Other researchers found a hidden prevalence of 35.1 cases in Fernandópolis, suggesting that unidentified cases may be possible sources of transmission and maintenance of the leprosy (NARDI, et al, 2013).

On the other hand, the decrease in new cases detected in 2009 in the municipality of Igarapé-Açu, which contributed to the municipality leaving the hyperendemic situation, was also observed in the city of Bayeux Paraíba, where researchers observed a decrease in the number of cases starting in 2009 (SILVA, RM, et al, 2012).

The map of the spatial distribution of the total cases of leprosy in the studied area presented a pattern of distribution of mosaic points, that is, several foci that comprised territorial areas with serious problems of basic sanitation, culminating in serious health risks of the resident population in areas near the course of the igarapé that runs through the locality; central areas and areas that harbored the beginning of the process of colonization of the community, also based on socio-demographic factors, whose many individuals do not have a high income and in many residences share or cohabit of the same environment for the accomplishment of domestic tasks, for example.

A recent study carried out in the community pointed out that precarious living conditions or family income, poor sanitation and life conditions and low level of schooling contribute even more to the emergence of new cases of leprosy (FRANCO MCA, 2014).

Similar data were also observed by Fausto, et al. (2010) when analyzing the municipality of Lagoa Grande (PE) through the geospatial analysis, and finding a concentration of leprosy cases near the lagoons and streams of the municipality.

Spatial analysis taking into account cumulative prevalence revealed a hyperendemic area throughout the community. However, when analyzing punctually, there were differences in the distribution of the cases in the micro-areas surveyed. In the city of Fernandópolis (SP) it was possible to identify areas with low endemicity and others with hyperendemic status, but also identified census tracts with mean detection coefficient for the period and several sectors with null coefficients in the period, demonstrating a unequal distribution of the disease within the urban area of the municipality (MERCARONI DA, 2003).

The Kernel analysis generated a density map, which despite not presenting a homogeneity presents some variation of the most concentrated foci, such as in microarea 6 , which contains health and microarea units 5 , which house the elderly with leprosy, revealing the so-called " hot areas ", which correspond to the highest number of concentration cases detected within a given area or areas. Although the data demonstrate micro areas with more cases of the disease, not all of them appear to be at high risk, since the large geographic area and the distance between the cases influence the calculation of the core density, another difference can also be explained in relation to the operational factors, such as the lack of adequate assistance or underreporting of cases in certain areas or to clinical factors (FRANCO MCA, 2014).

The influence of multibacillary cases on the distribution of cases in micr-areas showed a positive spatial correlation of strong intensity (Moran I $=0.71, p=0.022$ ). Similar results were observed in the municipality of Almenara (Minas Gerais), which identified a spatial autocorrelation between the census tracts of the Almenara microregion, in relation to the mean leprosy detection coefficients (AMARAL EP, LANA FCF, 2008). This confirms the importance of multibacillary cases in the transmission chain of leprosy, which reflects on the mode and disposition of cases of leprosy in a given area.

\section{CONCLUSION}

It is concluded that according to the data collected from 2003 to 2013, there is a dynamic in the process of illness and active transmission of leprosy in Vila Santo Antônio do Prata, considering urgent needs in the planning of adequate health policies, improvement of campaigns of action and combat and the constant monitoring of new cases, thus, contributing positively in the control of leprosy. 


\section{ACKNOWLEDGMENTS AND FINANCING}

To the Secretariat of Public Health of the State of Pará, to the Municipal Department of Health of the municipality of Igarapé-Açu that contributed to provide the necessary data to guide the search of the cases. To the employees of the State Shelter of Vila Santo Antônio do Prata, the Community Health Agents (ACS's) of the Basic Health Unit (UBS) and the population of the Village, who allowed access to their residences to collect the information, development and conclusion of this manuscript. This study did not count on any type of financing of institutional and / or private resources.

\section{REFERENCES}

1. Ministério da Saúde (BR). Secretária de Vigilância em Saúde. Coordenação Geral de Desenvolvimento da Epidemiologia em Serviços. Guia de Vigilância: [recurso eletrônico]/ Ministério da Saúde, Secretária de Vigilância em Saúde, Coordenação Geral de Desenvolvimento da Epidemiologia em Serviços. - 1. Ed. Atual. - Brasília: Ministério da Saúde, 2016.

2. RIDLEY DS, JOPLING WH. Classification of leprosy according to immunity - a five group system. Int J Lepr 1966; 34: 225-273.

3. IÑIGUEZ RL, GIL SR, RODRIGUEZ FC et al. Diferenciación geográfica en la trasmisión de la lepra en Cuba. Centro de Estudios de Ciencias Naturales, Universidad de la Habana, Ciudad de la Habana 1993. Informe final del proyecto SGP: 91-99.

4. SOUZA W. Academia Brasileira de Ciências. Doenças Negligenciadas. Rio de janeiro, 2010.

5. QUEIROZ JW, et al. Geographic information systems and applied spatial statistics are efficient tools to study Hansen's disease (leprosy) and to determinate areas of greater risk of disease. Am J Trop Med Hyg. 2010; 82(2): 306-14.

6. AMARAL EP, LANA FCF. Análise espacial da hanseníase na microrregião de Almenara, MG, Brasil. Rev. Brasileira de Enfermagem, Brasília, v.61, n. spe, p. 701-707, nov. 2008.

7. LANA FCF. Estimativa da prevalência oculta da hanseníase no Vale do Jequitinhonha - Minas Gerais. Revista Mineira de Enfermagem, Belo Horizonte, v.8, n.2, p.295-300, abr./jun. 2004.

8. BARRETO JG. Epidemiologia espacial e sorológica da hanseníase no Estado do Pará. 2013. [tese]. Belém: Universidade Federal do Pará, Programa de Pós-graduação em Doenças Tropicais do Núcleo de Medicina Tropical; 2013.

9. WHO. Leprosy elimination: Geographic Information Systems (GIS); b2015.

10. PENNA ML, et al. The epidemiological behavior of leprosy in Brazil. Lepr Rev. 2009 Sep; 80(3): 332-44. PubMed PMID: 19961107. eng.

11. ALENCAR $\mathrm{CH}$, et al. Clusters of leprosy transmission off late diagnosis in a highly indemic área in Brazil: focus on different spatial analysis approaches. Trop Med Int Health 2012 Apr; 17(4): 518-25. PubMed PMID: 22248041. eng.

12. SILVA FL, SILVA AL. Evolução de novos casos de hanseníase frente às políticas públicas adotadas na região amazônica: um estudo através de modelos de regressão, en Contribucionesa las Ciencias Sociales, Noviembre 2011.

13. MERCARONI DA. Análise espacial da endemia hansênica no município de Fernandópolis/SP. [tese]. Ribeirão Preto: Universidade de São Paulo; 2003.

14. NARDI, et al. Geoprocessamento em Saúde Pública: fundamentos e aplicações. Rev Inst Adolfo Lutz. São Paulo, v.72, n.3, p.185-91, 2013.

15. SILVA RM, et al. Análise espacial da endemia hansênica no município de Bayeux $(\mathrm{PB})$ mediante técnicas de SIG. Sociedade \& Natureza, v.24, n.2, p.345-358, 2012.

16. FRANCO MCA. - Dinâmica de transmissão da hanseníase em menores de 15 anos em área hiperendêmica na região Norte do Brasil [tese]. Belém: Universidade Federal do Pará, 2014. Tese (Doutorado em Doenças Tropicais) - Universidade Federal do Pará, Programa de Pós-graduação em Doenças Tropicais do Núcleo de Medicina Tropical; 2014.

17. FAUSTO, et al. Análise clínica, epidemiológica e espacial de pacientes com hanseníase em Lagoa Grande/Pe, por meio de tecnologias da geoinformação. - III Simpósio Brasileiro de Ciências Geodésicas e Tecnologias da Geoinformação Recife - PE, 27-30 de julho de 2010 p. 001 - 006. 